\title{
Racial Discrimination in Public Housing: Rights and Remedies
}

The Housing and Urban Development Act of $1968^{1}$ explicitly reaffirmed the policy enunciated by Congress in 1949 of providing a decent home for every American family. ${ }^{2}$ The achievement of that quantitative goal, however, is limited by prohibitions against perpetuating or increasing racial discrimination in housing. In recent years courts have carefully scrutinized low income public housing programs to determine whether their administration violates HUD's regulations, ${ }^{3}$ the Civil Rights Acts, ${ }^{4}$ or the equal protection guarantees of the Constitution. ${ }^{5}$ Since participation in public housing is an essentially voluntary under-

1 Housing and Urban Development Act of 1968 § 1601, 42 U.S.C. § 1441a (1970).

2 Housing Act of $1949 \S 2,42$ U.S.C. $\S 1441$ (1970). Congress first authorized a federal public housing program in the United States Housing Act of 1937, 42 U.S.C. $\$ \S 1401$ et seq. (1970), which established the United States Housing Authority (USHA) within the Department of Interior. The USHA was transferred to the Federal Works Agency in 1939, then was joined with the Federal Housing Administration (FHA) under a National Housing Agency in 1942, with the public housing programs being administered under a new semi-autonomous subagency called the Public Housing Agency (PHA). In 1949 the Fousing and Home Finance Agency became the new overseer of federal housing programs, and it was brought into the Department of Housing and Urban Development (HUD) upon HUD's formation in 1965. See Ledbetter, Public Housing-A Social Experiment Seeks Acceptance, 32 LAW \& ConteMr. Prob. 490, 493 (1967).

3 See, e.g., Shannon v. HUD, 436 F.2d 809 (3d Cir. 1970).

4 Cf. Blackshear Residents Organization v. Housing Authority, 347 F. Supp. 1138 (W.D. Tex. 1972). Title VI of the Civil Rights Act of 1964, 42 U.S.G. $\S 2000 \mathrm{~d}$ (1970), prohibits discrimination on the basis of race, color, or national origin in the administration of federally assisted programs. Title VIII of the Civil Rights Act of 1968, 42 U.S.C. $\$ \S 3601-3619$ (1970), deals primarily with private discrimination in housing, but also requires the Secretary of HUD to administer all programs "in a manner affirmatively to further" fair housing policies. 42 U.S.C. $\S 3608$ (d)(5) (1970). Prior to the passage of the 1964 Civil Rights Act, a 1962 Executive Order on Equal Opportunity in Housing, Exec. Order No. 11063, 3 C.F.R. 652 (Comp. 1959-63), directed federal agencies to "take all action necessary and appropriate" to prevent racial discrimination in federally assisted housing programs where the assistance contract was entered into after the date of the Order. The Public Housing Authority did not take an expansive interpretation of its vague powers under the Order. See Note, The Public Housing Administration and Discrimination in Federally Assisted Low-Rent Housing, 64 MrcH. L. REv. 871, 879 (1966) [hereinafter cited as Discrimination in Low-Rent Housing].

5 See, e.g., Gautreaux v. Chicago Housing Authority, 296 F. Supp. 907 (N.D. Ill. 1969). The equal protection clause of the fourteenth amendment applies only to the states, but the Supreme Court has made it clear that the same restrictions apply to federal action through the due process clause of the fifth amendment. Bolling v. Sharpe, 347 U.S. 497 (1954). 
taking by local authorities, ${ }^{\circ}$ federally imposed restrictions that do not coincide with the self-perceived interests of the localities tend to defeat the national housing policy by causing localities to refuse to conduct or cooperate in housing programs. Nevertheless, where a housing project is found to have been constructed or maintained in a manner inconsistent with the equal protection guarantees of the Constitution, the constitutional violation must be remedied. At least one court has held that such a violation can be cured only by restricting the control of local authorities over the selection of sites for new projects and has ordered the construction of new projects in specified areas of the city. ${ }^{7}$ It appears clear, however, that localities do not have sufficient funds of their own to engage in the construction of public housing. ${ }^{8}$ Courtordered construction, to remedy even constitutional defects, is therefore dependent on the existence of federal funding.

As a result of dissatisfaction with the overall shortcomings of the current program there is a likelihood that Congress will enact legislation providing for direct cash assistance to low-income tenants and will eventually terminate federal financing of construction of public housing. ${ }^{9}$ If such an alternative program is adopted, the courts will have to face the problem of fashioning appropriate remedial orders within the framework of the new program to cure constitutional violations that arose under the prior statutory scheme.

This comment discusses the evidentiary showing required to hold a local housing authority or HUD guilty of violating the equal protection clause in its administration of the public housing system as it currently exists. The comment then suggests ways in which these violations can

- A qualified Local Housing Authority must make application for federal assistance, show a need for low-rent housing that is not being fulfilled by private enterprise, and enter into a Cooperation Agreement with the governing body of the locality before HUD may finance the building of low-rent public housing. 24 C.F.R. $\$ 275.3$ (1978).

7 Gautreaux v. Chicago Housing Authority, 804 F. Supp. 736 (N.D. Ill. 1969) (judgment order).

8 See Ledbetter, supra note 2, at 521; Roisman, The Right to Public Housing, 39 GEo. WASH. L. REv. 691, 692 (1971).

8 President Nixon has stated that public housing has failed to provide adequate or decent housing, and has indicated that on the basis of HUD's major housing study of 1973, direct cash assistance is the most probable alternative program which the federal government will undertake. 119 Cong. Rec. S 16861, S 16864 (daily ed. Sept. 19, 1973) (President Nixon's message to Congress). The Senate held hearings on the Administration bill, S. 2507, 98d Cong., 1st Sess. (1973), which would establish a cash assistance pilot program, but on March 11, 1974, passed an alternative bill which would reestablish the public housing program and allow an extension and expansion of the experimental housing allowance program, S. 3066, 99d Cong., 2d Sess., ch. II, § 201, and ch. VIII, § 802 (1974). See notes 95-96 infra. 
be remedied under a federal program of direct cash assistance to lowincome tenants.

\section{Elements of a Denial of Equal Protection in Public Housing}

Challenges to the administration of public housing systems as denying equal protection to tenants have focused on segregative practices in site selection ${ }^{10}$ and tenant assignment. ${ }^{11}$ When a plaintiff demonstrates that the local housing authority has deliberately sought to place projects that will be occupied by racial minorities in minority areas, or has intentionally assigned Blacks to certain projects and Whites to others, discrimination in violation of the Constitution has been shown..$^{12}$ The state can offer no countervailing interest sufficient to justify the intentional discrimination. ${ }^{13}$ The public housing cases, therefore, have dealt primarily with whether the actions of the state are sufficient to permit a finding of intentional discrimination. Definition of a sufficient

10 See, e.g., Gautreaux v. Chicago Housing Authority, 296 F. Supp. 907, 909-14 (N.D. Ill. 1969); Hicks v. Weaver, 302 F. Supp. 619, 621-24 (E.D. La. 1969). The Local Housing Authority has initial responsibility for selecting sites for public housing construction, HUD Handbook 7410.1, Low-Rent Public Housing Preconstruction, para. 1-6(a) (1974), and until the promulgation of strict selection criteria by HUD, it could effectively control the ultimate selection by narrowing the alternatives that were presented to HUD for final approval. See notes 54 \& 60 infra.

11 See, e.g., Taylor v. City of Millington, 476 F.2d 599 (6th Cir. 1973); Gautreaux v. Chicago Housing Authority, 296 F. Supp. 907, 909 (N.D. Ill. 1969). Tenant assignment procedures of local housing authorities have similarly come under stricter control by HUD. See notes 54, 55 \& 65 infra.

12 The guarantee against denial of the "equal protection" of the laws" by state administrative or legislative action is a guarantee against differential treatment on the basis of unreasonable or arbitrary classification. Equal protection doctrine has developed into essentially a two-tier standard of review, with minimal scrutiny of state actions except where a "suspect class" of plaintiffs or a "fundamental interest" is affected, in which case the required showing of a "compelling" state interest is a virtually insurmountable bar to justi. fication. See generally Developments in the Law-Equal Protection, 82 HARv. L. Rev. 1065 (1969). The pre-eminence of the two-tier standard is currently in question, as alternative formulations aimed at a less conclusory operation of judicial review are suggested. See, e.g., Vlandis v. Kline, 412 U.S. 44I, 458 (1973) (White, J., concurring); San Antonio Indep. School Dist. v. Rodriguez, 411 U.S. 1, 70-133 (1973) (Marshall, J., dissenting); Gunther, The Supreme Court, 1971 Term-Foreword: In Search of Evolving Doctrine on a Changing Court: A Model for a Newer Equal Protection, 86 HARv. L. Rev. 1 (1972). Under all the alternative formulations, however, a classification scheme based on race is subject to the strictest scrutiny and can be justified only by a very important countervailing state interest.

13 Only one case, Korematsu v. United States, 323 U.S. 214 (1944), has found a state interest sufficient to justify state discrimination on the basis of race; the overriding state interest in that case was national security in time of war. See Crow v. Brown, 332 F. Supp. 382, 392 (N.D. Ga. 1971); Kennedy Park Homes Ass'n v. City of Lackawanna, 318 F. Supp. 669, 695-96 (W.D.N.Y. 1970). 
evidentiary showing is essential to understanding the nature of what may properly be called unconstitutional discrimination and to shaping effective and responsive remedies.

\section{A. The Prima Facie Violation of Equal Protection by the Local Housing Authority: ${ }^{14}$ Creation and Rebuttal}

1. The Plaintiff's Burden. Every legislative or administrative action has three basic components-the explicit operative rule, the objectives or purposes underlying the rule, and the effects of the rule. ${ }^{15} \mathrm{~A}$ clear case of intentional racial discrimination is made out when the plaintiff can show that either the explicit operative rule ${ }^{16}$ or the legislative objectives ${ }^{17}$ are constitutionally suspect or impermissible. ${ }^{18}$ Where, however, the plaintiff makes only a statistical showing of segregationof suspect effects without impermissible operative rules or objectivesthe plaintiff's burden will not be satisfied.19 The requirement that more than just segregative effects be shown to establish a prima facie violation arises from the state action requirement of the fourteenth amendment. If racially differential effects of the operation of a government program appear to be the totally fortuitous result of an unforeseeable independent force, the discrimination is not attributable to the state's action. Once knowledge of that force or of the probable consequences of the administrative action can be attributed to governmental officials, however, the showing goes beyond mere effect. It can

14 The local authority that administers the public housing system is a governmental entity, 24 C.F.R. $\$ 275.1(e)$ (1973), and may therefore be found to have violated the fourteenth amendment by its actions.

15 See Brest, Palmer v. Thompson: An Approach to the Problem of Unconstitutional Legislative Motive, 1971 Sup. CT. REv. 95.

16 See, e.g., Brown v. Board of Educ., 347 U.S. 483 (1954); Buchanan v. Warley, 245 U.S. 60 (1917). Early cases holding explicit segregation of public housing unconstitutional were Vann v. Toledo Metropolitan Housing Authority, 113 F. Supp. 210 (N.D. Ohio 1953); Banks v. Housing Authority, 120 Cal. App. 2d 1, 260 P.2d 668 (1st Dist. 1953), cert. denied, 347 U.S. 974 (1954); Detroit Housing Comm'n v. Lewis, 226 F.2d 180 (6th Cir. 1955).

17 See, e.g., Yick Wo v. Hopkins, 118 U.S. 356 (1886).

18 Impermissibility is created by explicit or unarticulated but inevitable disadvantaging of the minority. Residential segregation arguably produces the same kinds of psychological injury, deterioration of physical surroundings, and loss of associational benefits as are produced by segregated schools, making state-created residential segregation impermissible per se. See generally C. Abrams, Forbidden NEIGHBors 18-28, 70-80 (1955); D. MICENTIRE, RESIDENCE AND RACE 67-10I (1960); cf. Trafficante v. Metropolitan Life Insurance Co., 409 U.S. 205 (1972). But see, e.g., Piven \& Cloward, The Case Against Urban Desegregation, 12 Soclal WOrk 12, 18-21 (1967); S. Carmichael \& C. Hamilton, Black Power 54-56 (1967); cf. Vieira, Racial Imbalance, Black Separatism, and Permissible Classification by Race, 67 MrCH. L. REv. 1553, 1618-25 (1969). Even if the school analogy is not adopted, explicit separation of the races by the state is suspect and presumptively unconstitutional.

19 See Brest, supra note 15, at 110; cf. Jefferson v. Hackney, 406 U.S. 535, 549-50 (1972). 
then be argued that a presumptive intention to achieve or maintain the segregative result was operative in the decision to undertake the general practice that produced that result..20

There are difficulties, however, in articulating the factors that must be present, in addition to a showing of effect, to permit such a presumption. ${ }^{21}$ The courts are wary of examining the subjective motivations underlying a single administrative decision that produces suspect results but is innocent on its face or explainable in terms of an innocent purpose. ${ }^{22}$ In cases involving the administration of an entire public housing system, however, a composite of factors may properly establish the systematic application of racial criteria. ${ }^{23}$

In Gautreaux v. Chicago Housing Authority, ${ }^{24}$ the court inferred a deliberate policy of perpetuation of residential segregation in Chicago and within the public housing system. The inference of intentional discrimination arose from a showing of three factors: first, a pre-1954 policy of explicit segregation and a continuing policy of quota assignment which kept certain projects substantially White, ${ }^{25}$ second, a finding that more than 99 percent of the units occupied by Black tenants were in projects located in Black neighborhoods; ${ }^{26}$ and third, site selection procedures that resulted in the rejection by the Chicago City Council and the Chicago Housing Authority of over 99 percent of the sites proposed in White areas and only 10 percent of the sites proposed in Black areas. ${ }^{27}$ The prior history of intentional discrimination plus the improbability that segregation of this magnitude could result from causes other than purposeful discrimination made it appropriate to put

20 See, e.g., Bradley v. Milliken, 338 F. Supp. 582, 592 (E.D. Mich. 1971); Fiss, Racial Imbalance in the Public Schools: The Constitutional Concepts, 78 HARv. L. Rev. 564, 584-85 (1965); cf. Norwalk CORE v. Norwalk Redevelopment Agency, 395 F.2d 920, 931(2d Cir. 1968); Garrett v. City of Hamtramck, 335 F. Supp. 16, 23-25 (E.D. Mich. 1971).

21 In some of the jury exclusion cases, evidence of particular practices of the state officials responsible for selecting jurors was adduced to supplement the purely statistical evidence on the effects of the selection process. See, e.g., Whitus v. Georgia, 385 U.S. 545 (1967). Where statistical evidence alone was offered to prove discrimination, the Court required that the data show effects of sufficient mathematical improbability to indicate some covert systematic exclusion of minorities. See, e.g., Swain v. Alabama, 380 U.S. 202, 208-09 (1965); Hernandez v. Texas, 347 U.S. 475 (1954); cf. Whitus v. Georgia, 385 U.S. at 552 n.2. The degree of mathematical improbability of the actual effects may determine the probative strength of statistical evidence. See text and note at note 41 infra.

22 Palmer v. Thompson, 403 U.S. 217, 224-25 (1971); United States v. O'Brien, 391 U.S. 367, 383-84 (1968); Fletcher v. Peck, 10 U.S. (6 Cranch) 87 (1810).

23 See Brest; supra note 15, at 105.

24296 F. Supp. 907 (N.D. Ill. 1969).

25 Id. at 909 .

26 Id. at 910.

27 Id. at 911-12. 
the burden on the defendant to show the absence of racial discrimination. The presumption of intentional discrimination could be rebutted only by a showing that racial criteria were not used in selecting sites;28 the Chicago Housing Authority was unable to make that showing. The court held insufficient the justification that racial differentiation was motivated by a desire to fill the housing need without exacerbating local opposition in White areas. ${ }^{29}$

In Hicks v. Weaver, ${ }^{30}$ decided several months later, another federal district court applied the same principles in evaluating the public housing program of Bogalusa, Louisiana. A presumptive violation of the fourteenth amendment was established by three sets of evidence: that the local authorities considered only sites in ghetto areas for a new project intended to house displaced Blacks; a recently abandoned official policy of segregative tenant assignment and site selection; and the continued segregated occupancy of existing projects. ${ }^{31}$ It was suggested by the court that the presumption could be rebutted by a showing that no acceptable sites other than those in Black neighborhoods were available, but as in Gautreaux, the defendant housing authority could not make that showing.

In a more recent case, the public housing program of Gleveland, Ohio, was held to have been administered in violation of the fourteenth amendment and the Civil Rights Acts. ${ }^{32}$ The plaintiff showed that most new public housing projects had been placed in minority areas of the city, that city officials had rejected certain privately-developed, subsidized low-income projects in White areas of the city, and that a referral system of tenant assignment had been used that required tenant applications to be processed through project managers who were of the same race as the majority of tenants in the segregated projects and in the segregated surrounding neighborhoods. The court found that there had been no satisfactory showing of an alternative explanation for the city's denial of building permits for the proposed Whitearea projects. ${ }^{33}$ The court also held that good faith operation of the housing system by the Cleveland Metropolitan Housing Authority was

$28 I d$. at 913.

29 Id. at 914.

30302 F. Supp. 619 (E.D. La. 1969).

31 Id. at 623. The Bogalusa Housing Authority's presumptively purposeful discrimination was held also to violate Title VI of the Civil Rights Act of 1964, 42 U.S.C. $\$ 2000 \mathrm{~d}$ (1970). HUD was held in violation of the same Act as an active participant through its approval and funding of the segregated system. 302 F. Supp. at 623.

32 Banks v. Perk, 341 F. Supp. 1175 (N.D. Ohio 1972).

33 Id. at 1179. 
no defense where the natural and probable effect of its actions was known to be the perpetuation of residential segregation. ${ }^{34}$

By contrast, another federal district court found no prima facie violation on a roughly similar set of facts. ${ }^{36}$ The court denied a motion for a preliminary injunction against construction of a project in a Black area of Miami, holding that the defendant had shown to the court's satisfaction that the site selection was "motivated solely by community needs."38

The holdings in these cases may provide some insight into factors that, when combined with a showing of segregation within the public housing system, will trigger a presumption of intentional racial discrimination on the part of the local housing authority. The plaintiff may produce evidence of the historical context, immediate objectives, and both foreseeable and actual effects of the challenged public housing practices in attempting to establish a presumption that the practices involved the use of racial criteria. ${ }^{37}$

Although the holdings of two district courts do not conclusively define the law, ${ }^{38}$ a comparison of the Miami with the Bogalusa case ${ }^{39}$ may be instructive as to the general limits of the required evidentiary showing. The Bogalusa Housing Authority had maintained an official policy of segregation until 1968, while the Miami Housing Authority had abandoned its explicitly segregative policy in favor of an official policy of nondiscrimination prior to the effective date of the Civil Rights Act of 1964. The contested site in Miami was located in a racially mixed area, rather than a completely Black area as in Bogalusa, and the degree of actual segregation within the Miami public housing system was less than that in Bogalusa's. Finally, the Miami site was chosen after consultation with and explicit approval by representatives of the Black community, a process not followed in Bogalusa. The difference between the two cases seems to be one of degree, dependent on the peculiar history and background of the selection of a challenged site or of the administration of a locality's entire system. Generalized quantification of the plaintiff's burden may thus be impossible.

The potential elements of a plaintiff's indirect proof of discrimination may, however, be assigned relative weights based on their relative

\footnotetext{
.34 Id. at 1183.

35 Thompson v. Housing Authority, 251 F. Supp. 121 (S.D. Fla. 1966).

36 Id. at 124.

37 Cf. Reitman v. Mulkey, 387 U.S. 369, 373 (1967).

38 There is the additional complication that a possibly determinative factor in Thompson was the plaintiff's failure to appear for testimony at the hearing. $251 \mathrm{~F}$. Supp. at 129.

39 Thompson v. Housing Authority, 251 F. Supp. 121 (S.D. Fla. 1966), and Hicks v. Weaver, 302 F. Supp. 619 (E.D. La. 1969), respectively.
} 
probative strength. Statistical evidence as to the results of the site selection and tenant assignment procedures is essential to the showing of a racial classification. ${ }^{40}$ In general, statistical evidence of segregative results serves merely as a threshold to an indirect showing of racial discrimination, but segregative results may also be influential to the extent that they compel the conclusion that only consistent application of racial criteria could have produced them. ${ }^{41}$

The next most important element of proof involves facts surrounding the current administration of the housing program, which may bear on the administrators' objectives. Such facts are necessarily peculiar to each case, and may vary widely in probative strength. Examples range from an admission that the authority used factors that correlate highly with race, to the existence of an informal system of aldermanic veto of sites in a racially segregated city, ${ }^{42}$ to the existence of waiting lists for housing that are composed almost entirely of minorities. ${ }^{43}$

40 As of 1968, 77.7 percent of all PHA projects were completely segregated in occupancy. Public Housing Administration, Trends Toward Open Occupancy, Report No. 12, at Table I (1963). Current data for racial occupancy by project is reported semi-annually to HUD by all local housing authorities, but no compilation is made. Telephone Interview with Jeffrey Frant, Equal Opportunity Specialist, HUD, Washington, D.C., January 9, 1974. It seems likely that actual segregation in some degree is the normal situation in most localities, due to the historical existence of officially segregative policies, the existence of private discrimination in the housing market, and the relatively recent appearance of HUD project selection and tenant assignment guidelines of more than advisory weight. Further, the steadily increasing identification of public housing as Black housing because of the relative unavailability to Blacks of private units has created situations in which nonminority site location is resisted by local residents, and placement of racially nondesignated public housing on minority sites produces Black housing in Black neighborhoods. See Gautreaux v. Chicago Housing Authority, 296 F. Supp. 907 (N.D. Ill. 1969); D. McENTIRE, supra note 18, at 324-25; Friedman, Government and Slum Housing: Some General Considerations, 32 LAw \& Contemp. ProB. 357, 362 (1967).

41 See, e.g., Gautreaux v. Chicago Housing Authority, 296 F. Supp. 907 (N.D. IIl. 1969): "It is incredible that this dismal prospect of an all Negro public housing system in all Negro areas came about without the persistent application of a deliberate policy to confine public housing to all Negro or immediately adjacent changing areas." Id. at 910. The statistics in that case showed "a very high probability, a near certainty, that many sites were vetoed on the basis of the racial composition of the site's neighborhood." Id. at 913.

42 Id. at 909-12. A similar allegation of City Council rejection of White sites has been made in a suit brought in Memphis, Tennessee. Hale v. HUD, Givil No. 73-410 (W.D. Tenn., filed Sept. 20, 1973).

43 Gautreaux v. Chicago Housing Authority, 296 F. Supp. 907, 909 (N.D. Ill. 1969); Hicks v. Weaver, 302 F. Supp. 619, 621 (E.D. La. 1969). Other examples of seemingly neutral actions in relation to subsidized housing other than public housing that courts have held in context to constitute illegal discrimination are the denial of building permits to nonminority-site low-income housing projects, Crow v. Brown, 332 F. Supp. 382 , 389 (N.D. Ga. 1971); the rezoning of a proposed nonminority site to open space use, declaration of a moratorium on subdivision building, and denial of a sewer extension application, Kennedy Park Homes Ass'n v. City of Lackawanna, 436 F.2d 108, 113-14 (2d Cir. 1970), cert. denied, 401 U.S. 1010 (1971); and the denial of rezoning and building permit applications for 2 
Third in weight among the evidentiary elements that the plaintiff may use is proof of a history of discrimination. Again, the probative strength of such evidence may vary rather widely. Virtually every local housing authority has at one time pursued an explicit policy of racial segregation, ${ }^{44}$ but the relevance of that historical policy to the existence of a currently covert one depends greatly on the policy's original scope and ultimate duration.45 Evidence of historical context is neither conceptually necessary, as with statistical proof of differentiation, nor potentially determinative..$^{46}$

2. Rebutting the Prima Facie Case. After the plaintiff has established a prima facie case of intentional discrimination, the defendant has the burden of proving that he did not use racial factors in making his decision. ${ }^{47}$ Mere assertion of the absence of such use or of good faith consideration of valid alternative factors is insufficient, ${ }^{48}$ although satis-

single project, Dailey v. City of Lawton, 296 F. Supp. 266, 268 (W.D. Okla. 1969), aff'd, 425 F.2d 1037 (10th Cir. 1970). See generally Sisters of Providence of St. Mary of the Woods v. City of Evanston, 335 F. Supp. 396, 403-05 (N.D. Ill. 1971), collecting cases within categories of typical fact patterns.

44 Information as to the number of local housing authorities that have had explicit policies of racial segregation or racial differentiation in site selection or tenant assignment is not available from HUD. Letter from Julian B. McKay, Acting Director, Office of Housing Programs, HUD, to The University of Chicago Law Review, December 10, 1973. One study indicates, however, that most localities originally chose to pursue such policies. D. MCENIIRE, supra note 18, at 319-21. As of March 31, 1953, seven Northern states, the District of Columbia, and some localities in two other states had explicit open occupancy policies, while fifteen of the remaining thirty-nine states had no policy but did have some integrated projects. Public Housing Administration, OpEN Occupancy IN Housing Pro. GRAMS, Report No. 2 (1953). By 1963, thirty-three states and the District of Columbia (comprising 452 localities) had open occupancy policies, fifteen of the thirty-three prohibited discrimination in public housing by law, and the remaining twelve states in the public housing program (comprising 831 localities) still had no policy. PuBLic Housing Administration, TREnds Toward Open Occtpancy, Report No. 12, at i, vii (1963).

45 Compare Hicks v. Weaver, 302 F. Supp. 619 (E.D. La. 1969), with Thompson v. Housing Authority, 251 F. Supp. 121 (S.D. Fla. 1966).

$46 \mathrm{An}$ explicit policy of discriminatory site selection in the past has relevance to the responsibility of current defendants who continue to administer the segregated housing that the policy produced when the remedy sought is directed primarily at curing the racially disproportionate availability of units which has resulted. The causal link between present segregation and a historical discriminatory tenant assignment policy is more difficult to establish, but where the policy was so recent that its administrators are the current administrators of a program that has remained segregated, historical evidence is clearly relevant to the question of whether those administrators should be held liable to cure the effects of prior discrimination.

47 Gautreaux v. Chicago Housing Authority, 296 F. Supp. 907, 913 (N.D. IIl. 1969); cf. Keyes v. School Dist. No. 1, 413 U.S. 189, 210-12 (1973).

48 Dailey v. Gity of Lawton, 425 F.2d 1037, 1039 (10th Cir. 1970); Banks v. Perk, 341 F. Supp. 1175, 1183 (N.D. Ohio 1972); Gautreaux v. Chicago Housing Authority, 296 F. Supp. 907, 914 (N.D. Ill. 1969); cf. United States v. Board of School Comm'rs, 474 F.2d 81, 84-85 (7th Cir. 1973), cert. denied, 413 U.S. 920 (1973). 
factory proof of the negative proposition is obviously quite difficult. It has been suggested that the absence of racial criteria might be proved by showing that no sites in White areas were available, ${ }^{40}$ but the standard of availability in this instance must be rigorous. ${ }^{50}$ Some allegedly nonracial criteria are so highly correlated with race that courts have held, as a matter of law, that their use constitutes racial discrimination. An example of such a criterion is concern for avoiding local opposition to low-income housing ${ }^{51}$ or school integration ${ }^{52}$ in nonminority areas. The nonracial criteria must also not be such as will interact with private patterns of discrimination to produce readily foreseeable segregative effects. The legal maxim that one is presumed to have intended the foreseeable consequences of his acts is operative in this area. ${ }^{53}$ Thus, where it is foreseeable that state action will result in segregation, it is appropriate that the authorities be held to have intended the segregation.

In order for the defendant local housing authority to overcome a presumption of intentional discrimination arising from a demonstration of segregative effects, a history of discrimination, and other factors indirectly bearing on intent, it must prove that the only criteria it actually considered in making its site selections and tenant assignments were neither highly correlated with race nor produced readily foreseeable segregative results.

\section{B. The Prima Facie Violation of Equal Protection by HUD}

The Department of Housing and Urban Development has been held liable for the segregative administration of public housing, in the provision of which it is an indispensable participant. HUD's predecessors, like many of the local housing authorities, explicitly fostered racial discrimination in the early development of the public housing

49 Hicks v. Weaver, 302 F. Supp. 619, 623 (E.D. La. 1969).

50 Cf. 5 HARv. Grv. Rights-Civ. Lib. L. REv. 150, 155 (1970). Where systematic application of a racial criterion has been shown, unavailability less than virtual nonexistence, for example due to relative cost, is merely an alternative explanation of the action, and is not sufficient to prove that the racial criterion was not considered. The court will not make a subjective inquiry to determine which consideration actually predominated in the minds of the administrators. Where, however, a single subsidized project is prevented from being built in a nonminority area, a prima facie showing of the use of any systematic racial criterion that operates to reject White sites and allow Black sites may be impossible. See Sisters of Providence of St. Mary of the Woods v. City of Evanston, 335 F. Supp. 396, 404 (N.D. Ill. 1971). In such situations, the difficult task of assessing conflicting "motives" or "purposes" of the state officials arises. See Brest, supra note 15, at 112-18.

51 Gautreaux v. Chicago Housing Authority, 296 F. Supp. 907,914 (N.D. Ill. 1969).

52 Cooper v. Aaron, 358 U.S. 1 (1958).

53 See authorities cited note 20 supra. 
and private mortgage insurance programs..$^{54}$ The policies have gradually changed $^{55}$ in response to Executive Order $11063^{56}$ and the Civil Rights Acts of $1964^{57}$ and $1968,{ }^{88}$ and HUD was finally compelled by the decision in Shannon v. HUD ${ }^{59}$ to promulgate comprehensive Project Selection Criteria ${ }^{60}$ and tenant selection procedures. ${ }^{61}$ These changes in policy, however, do not absolve HUD from liability for its past discrimination. HUD has been found in violation of the equal protection clause $e^{62}$ through its active segregative policy and through its knowing acquiescence in the discriminatory practices of local housing authorities. ${ }^{63}$ HUD participates in the planning and has final responsi-

54 The FHA was most explicit in its administration of the mortgage insurance program, officially encouraging racially restrictive covenants by property owners and the "red-lining" of potentially transitional neighborhoods by its appraisers from 1938 until 1947. See C. ABRAMS, supra note 18, at 229-37; D. MCENTIRE, supra note 18, at 301; U.S. CoMM'N on Civil Richts, REPORT, Book 4: Housing 16 (1961). Public housing provided from the inception of the program through World War II was, for the most part, segregated. Id. at 17,28 ; D. MCENTIRE, supra note 18, at 318. Racial policies were left to the local agencies, whose authority to maintain segregated sites was upheld on the basis of the separate but equal doctrine. See, e.g., Favors v. Randall, 40 F. Supp. 743 (E.D. Pa. 1941); Housing Authority v. Higginbotham, I43 S.W.2d 95 (Tex. Civ. App. 1940). The PHA's official policy after 1949 became a requirement of "equitable provision [of public housing] for eligible families of all races," even if segregated. PUblic Housing Administration, Low-Rent Housing Manual § 102.1 (1951); see Heyward v. Public Housing Administration, 238 F.2d 689, 697 (5th Cir. 1956) (fifth amendment claim lay against PHA for failing to supply housing on the basis of need, because its "equitable provision" policy allowed an explicit policy of racial segregation by the local housing authority, citing Bolling v. Sharpe, 347 U.S. 497 (1954)); U.S. CoMm'N ON Crvil. RIGHTs, supra, at 143. See generally Note, Discrimination in Low-Rent Housing, supra note 4.

55 Compare Public Housing Administration, Low-Rent Housing Manual § 102.1 (1963), with Public Housing Administration, Low-Rent Housing Manual $§ 102.1$ (1965); see note 40 supra.

563 C.F.R. 652 (Comp. 1959-63); see note 4 supra.

5742 U.S.C. $\$ 2000 \mathrm{~d}$ (1970); see note 4 supra.

8842 U.S.C. $\$ \$ 3601-3619$ (1970); see note 4 supra.

89 436 F.2d 809 (3rd Cir. 1970). Shannon established a statutory duty on HUD's part to consider the racial effect of the placement of a single rent supplement project (higher income than public housing) in a minority area.

6024 C.F.R. $\$ 200.710$ (1973). These criteria, effective since 1972, provide for the automatic rejection of most projects proposed to be built in minority areas. See generally Maxwell, HUD's Project Selection Criteria-A Cure for "Impermissible Color Blindness"?, 48 NOTRE DAME LAW. 92 (1972).

61 See 24 C.F.R. \& 1.4(b)(2)(ii)(1973).

62 The Seventh Circuit in Gautreaux v. Romney, 448 F.2d 731, 738 (7th Cix. 1971), held HUD to the same standard under the fifth amendment as applies to states under the fourteenth, relying on Bolling v. Sharpe, 347 U.S. 497 (1954).

63 This acquiescence has taken the form of approval of expedient but nonqualifying sites. Gautreaux v. Romney, 448 F.2d 731, 737-40 (7th Cir. 1971), 363 F. Supp. 690 (N.D. III. 1973) (judgment order); cf. Blackshear Residents Organization v. Housing Authority, 347 F. Supp. 1138, 1146-48 (W.D. Tex. 1972). But see Croskey Street Concerned Citizens v. Romney, $459 \mathrm{~F} .2 \mathrm{~d} 109$ (3rd Cir. 1972), affrming the denial of an injunction against con- 
bility for approving the selection of sites $^{64}$ and the tenant assignment procedures. ${ }^{65}$ It is therefore clearly a partner in any racially discriminatory practices arising at the time of construction of a low-income housing project. Nor does HUD's participation end with the construction of the project, for it may contribute maintenance $\operatorname{costs}^{66}$ and, by virtue of the agreement between it and the local housing authority, may require the local authority to continue to administer the program under agreed-upon procedures and to change those procedures only with HUD's approval. ${ }^{67} \mathrm{~A}$ continuing violation on the part of local authorities is, therefore, a continuing violation by HUD.

HUD was held liable along with the local housing authority in both Gautreaux ${ }^{68}$ and Hicks. ${ }^{69}$ Evidence adduced by plaintiffs in each case concerned the Department's continuous involvement in the public housing process through funding and planning advice, and its approval of the segregative sites with knowledge of the racial circumstances and probable consequences.70 The Seventh Circuit in Gautreaux rejected HUD's contentions that it was not liable because its actions were performed in good faith or in accordance with the valid objective of fulfilling an urgent need for housing that could not be provided unless

struction of a HUD-approved low-rent housing project in a 95 percent Black area, on HUD's promise that a "balancing" White-area project would be built. The "balancing" exception is reflected in the Project Selection Criteria whereby a minority-area project is to be disfavored but not absolutely barred. 24 C.F.R. $\$ 200.710$, Criterion 2(B)(2) (1973). See also Coffey v. Romney, P-H Equal OpP. IN Housing I 13,588 (M.D.N.C. May 11, 1972), rejecting a challenge to HUD's approval of a section 236 project (higher income than public housing) in an originally predominantly White area that became racially mixed, because the project was shown not to promote increasing racial concentration. See 24 C.F.R. § 200.710, Criterion 2(B)(I) (1973).

64 HUD HandBook 7410.1, Low-RENT Public Housing Preconstruction, para. 1-6(c) (1974). The Project Selection Criteria, supra note 60, provide the relevant standard. $I d$. at para. I-2(h).

6524 C.F.R. § 1.4(b)(2)(ii) (1973). Acceptable plans must provide assignment from the top of a community-wide list, with from zero to two refusals of available vacancies allowed before the applicant is moved back to the bottom of the list. HUD HANDBOOK HM 7401.1, LOW-RENT Housing: ADMinistration of Program, Ch. 9, \& 1, App. 2, para. 1(d) (1973). "Freedom of choice" is used in this comment to refer to such plans. Cf. Gautreaux v. Chicago Housing Authority, 304 F. Supp. 736, $742-48$ (N.D. Ill. 1969) (judgment order).

6642 U.S.C. \$ 1410 (a) (1970).

67 Form HUD-53011, ANnUal Contributions Contract Part Two, TERMs and CoNDirions $\$ \S 201,202$ (1969). The government may take possession or title of the projects or terminate the contract at its option in the event that the low-rent character of the projects is not maintained or in case of other substantial default or breach. Id. at $\S \S 501,508$, 509; 42 U.S.C. § $1451(3)(1970)$.

68448 F.2d 731 (7th Cir. 1971).

69302 F. Supp. 619 (E.D. La. 1969).

70 Gautreaux v. Romney, 448 F.2d 731, 739 (7th Cir. 1971); Hicks v. Weaver, 302 F. Supp. 619, 623 (E.D. La. 1969). 
local racially-motivated opposition were avoided. ${ }^{71}$ Proof of HUD's efforts toward desegregation was held to be insufficient to negate liability for the intentional discrimination established through evidence of approval of the segregative sites. ${ }^{72}$

Recognition of HUD's liability is important if courts are to be successful in ordering effective remedies to cure the constitutional violation caused by intentional racial discrimination. Any remedy that goes beyond a mere prohibition of future discrimination will require the participation of HUD in the form of continued funding. ${ }^{73}$

\section{The Remedial Standard}

\section{A. The Content of the Equal Protection Guarantee in Public Housing}

A precise statement of the constitutional violation involved in the public housing cases is essential to an examination of the permissible and the appropriate remedies. Although the equity powers of a court in shaping relief for violations of the Constitution are broad, the relief granted must, of course, be limited to the curing of the violation. ${ }^{74}$ The Gautreaux judgment order ${ }^{75}$ has been severely criticized on the ground that it makes policy decisions beyond the competency of the court and beyond what is required by the fourteenth amendment. ${ }^{76}$ The Gautreaux court, however, seems correct in defining the right of the plaintiffs as a constitutional guarantee against state restriction of minorities to minority neighborhoods and minority projects through the conscious use of racial factors in shaping site selection and tenant assignment policies. ${ }^{77}$

71448 F.2d at 739. HUD's own Project Selection Criteria now allow approval of minority sites on the basis of overriding need only if the need is caused by forces other than racial opposition of local residents of nonminority areas. 24 G.F.R. $\$ 200.710$, Criterion 2(B)(3) (1973).

72 Gautreaux v. Romney, 448 F.2d 731, 738 (7th Cir. 1971). But cf. Crow v. Brown, 332 F. Supp. 382 (N.D. Ga. 1971). The district court there rejected the significance of HUD's role of approval, but dismissed the claim against HUD on the ground of its recent disapproval of segregative sites. The focus of the suit was the obstruction by county officials of construction on two White sites that HUD had already approved, and the court was unwilling to allow broader claims to attach liability to cooperative parties. 332 F. Supp. at 395.

73 Cf. Gautreaux v. Romney, 448 F.2d 731, 736-37 (7th Cir. 1971).

74 Swann v. Charlotte-Mecklenburg Bd. of Educ., 402 U.S. 1, 15-16 (1971).

75304 F. Supp. 736 (N.D. III. 1969).

76 See, e.g., Note, 44 N.Y.U.L. REv. 1172, 1181 (1969); Note, 22 VAND. L. REv. 1386, 1393 (1969); Note, 1970 Wis. L. Rev. 559, 568; Note, Public Housing and Urban Policy: Gautreaux v. Chicago Housing Authority, 79 YALE L.J. 712, 710-19, 724-29 (1969).

77 " $[P]$ laintiffs, as present and future users of the system, have the right under the Fourteenth Amendment to have sites selected for public housing projects without regard to the racial composition of either the surrounding neighborhood or of the projects themselves." 265 F. Supp. at 583. 
Some courts have responded to alternative claims under the Civil Rights Acts, ${ }^{78}$ and have held that beyond the constitutional duty not to use racial characteristics to the detriment of the rights of minorities within a public housing system, there is a statutory duty to promote integration, or take affirmative action to avoid segregation, by considering the racial impact of project placement in minority areas. ${ }^{70}$ This duty, however, is statutory only, and is not constitutionally required, ${ }^{80}$ if indeed constitutionally permitted. ${ }^{81}$

Strict delineation of the constitutional and statutory requirements has important ramifications for the remedies to be provided. Since a violation of the equal protection clause is not found in segregated occupancy alone, the remedial goal is not integrated occupancy per se. The constitutional violation consists of state-imposed racial discrimination and the appropriate remedy requires providing each public housing applicant with a fair opportunity to be assigned, by choice or by selection, to a public housing project that was selected, constructed, and administered without regard to racial characteristics. The lack of public housing projects in nonminority areas caused by discriminatory site selection as well as the psychological and sociological impact of state-imposed segregation, however, may require the temporary consideration of racial characteristics in order to achieve the racially neutral state necessary to ensure that minorities are not forced to take housing in minority areas.

B. Remedial Requirements for Discriminatory Site Selection and Tenant Assignment

Where an administrative mechanism has been used to obstruct the construction of individual low-income projects in nonminority areas, a simple injunction against the obstructing device is ordinarily a sufficient remedy. ${ }^{82}$ Where, instead of reactive attempts to maintain

78 Civil Rights Act of 1964, 42 U.S.C. § 2000d (1970); Civil Rights Act of 1968, 42 U.S.C. $\S$ 3608(d)(5) (1970); see text and notes at notes 4 \& 57-58 supra.

79 See, e.g., Shannon v. HUD, 436 F.2d 809 (3rd Cir. 1970); Blackshear Residents Organization v. Housing Authority, 347 F. Supp. 1138, 1146-48 (W.D. Tex. 1972); Crow v. Brown, 332 F. Supp. 382, 390-91 (N.D. Ga. 1971).

80 Contra, Banks v. Perk, 341 F. Supp. 1175, 1182 (N.D. Ohio 1972).

81 The acceptable limits of an affirmative duty to integrate have yet to be drawn. See Otero v. New York City Housing Authority, 484 F.2d 1122 (2d Cir. 1973), rev'g and remanding 354 F. Supp. 941 (S.D.N.Y. 1973); cf. DeFunis v. Odegaard, 94 S. Ct. 1704 (1974), dismissing as moot 82 Wash. 2d 11, 507 P.2d 1169 (1973).

82 See, e.g., Kennedy Park Homes Ass'n v. Gity of Lackawanna, 318 F. Supp. 669, 697 (W.D.N.Y.), aff'd, 486 F.2d 108 (2d Cir. 1970), cert. denied, 401 U.S. 1010 (1971), where defendant City was enjoined from condemning the site, from denying a sewer application, and from using any other devices to obstruct the low-income housing project's construction. Three years later, however, the court, having retained jurisdiction, was forced to order the City Planning Board to approve the project's final subdivision development plan. Kennedy 
residential segregation in the face of efforts to dilute it, the discrimination shown is the furtherance of racial segregation by placement of low-income housing projects expected to be inhabited by minority tenants in minority neighborhoods, construction of the individual projects may be enjoined. ${ }^{83}$

In cases involving proof of more institutionalized or broader discriminatory practices, however, the relief granted may require utilization of broader remedies to undo the complex remains of a long-standing system. These remedies will generally take the form of an injunction conditioning the future expenditure of funds. ${ }^{84}$ Where intentional discriminatory state action has resulted in restricting a predominantly Black group of tenants to Black sites, as was found in Gautreaux, the relief must provide for the opportunity to be assigned to White-site

Park Homes Ass'n v. City of Lackawanna, P-H Equal OPP. IN Housing \ 13,613 (W.D.N.X. June 12, 1973).

83 See, e.g., Blackshear Residents Organization v. Housing Authority, 347 F. Supp. 1138, 1150 (W.D. Tex. 1972); cf. North Avondale Neighborhood Ass'n v. Cincinnati Metropoli$\tan$ Housing Authority, 464 F.2d 486 (6th Cir. 1972).

84 It is by now clear that neither the state nor the federal government may be forced, by a private party, to give relief that requires the expenditure of money from the public fisc. Edelman v. Jordan, 94 S. Ct. 1347 (1974); Larson v. Domestic \& Foreign Commerce Corp., 337 U.S. 682 (1949). See also Employees of Dep't of Public Health \& Welfare v. Department of Public Health, 93 S. Ct. 1614 (1973); Land v. Dollar, 330 U.S. 731 (1947). No language in current enabling legislation appears to waive HUD's sovereign immunity defense, nor does the legislation require, by "clear language," the states' consent to affirmative relief. See 42 U.S.C. \& 1404a (1970); Employees of Dep't of Public Health \& Welfare v. Department of Public Health, supra. A local government may not raise a sovereign immunity defense against an order to make affirmative expenditures, Workman v. City of New York, 179 U.S. 552 (1900), but fiscal limitations and the potential for concurrent disproportionate injury to citizens who are thereby denied other governmental benefits make such a remedy unacceptable. Cf. note 8 supra \& note 100 infra.

The constitutional violation here considered, however, involves the ongoing expenditure of money by or under the direction of the municipality, state, or federal government. The pattern of segregation will be reinforced if money is expended on programs without remedial action being taken. It is therefore appropriate for the courts to require that any money that is expended be used in a manner that does not reinforce the constitutional violation. Where, for example, the court has ordered the municipal defendants to construct new housing as expeditiously as possible, and HUD has committed funds sufficient for such construction, the court may also order that only White sites be approved by HUD, an order which requires no increased expenditure of public funds. Once funds for" a housing allowance program have been allocated, similar conditions may be imposed on their expenditure-that the funds must be used so as to avoid reinforcing the pattern of segregation. See generally Serna v. Portales Municipal Schools, 351 F. Supp. 1279 (D.N.M. 1972); United States v. Texas, 342 F. Supp. 24 (E.D. Tex. 1971), aff'd, 466 F.2d 518 (5th Cir. 1972). But see Lau v. Nichols, 483 F.2d 791 (9th Cir. 1973), rev'd on other grounds, 94 S. Ct. 786 (1974).

It is also to be noted that in the public housing cases HUD has either waived its sovereign immunity defense, Gautreaux v. Romney, 448 F.2d 731, 735 (7th Cir. 1971), or has failed to raise it. 
projects. When there are no such projects in White areas because of racial discrimination in the site-selection process, it is necessary not only to prohibit discrimination in future choice of sites, but also to require the choice of White sites until the opportunity to be assigned to either a White-area project or a Black-area project exists for all tenants. ${ }^{85}$ The detailed Gautreaux judgment order $^{86}$ was thus conceptually justifiable insofar as it required the Chicago Housing Authority to use its best efforts to provide new housing units as rapidly as possible, ${ }^{87}$ with a greater proportion of the new sites placed in nonminority sections of the city. ${ }^{88}$

85 Hicks v. Weaver, 302 F. Supp. 619 (E.D. La. 1969), involved only a preliminary injunction against a proposed 100 -unit project in a Black area which was intended to accommodate only Blacks; there already existed 140 White units and 200 Black units, segregated by project occupancy and location. In Gautreaux v. Chicago Housing Authority, 304 F. Supp. 736 (N.D. Ill. 1969), the final order dealt with the entire system of segregated housing (four White projects and fifty Black projects, see 296 F. Supp. at 910), and required the construction of a substantial number of White-site projects, with the implementation of an essentially first-come, first-served tenant assignment plan. $304 \mathrm{~F}$. Supp. at 738-43. Where balancing projects exist in Black and White areas, the equal protection guarantee is satisfied by an objective tenant assignment system. Cf. Taylor v. City of Millington, 476 F.2d 599 (6th Cir. 1973). Although the authorities might attempt to cure the violation by demolishing existing projects in Black areas, this solution is unlikely to be accepted by the courts because of the requirement that an equitable remedy must balance public and private interests. Cf. North Avondale Neighborhood Ass'n v. Cincinnati Metropolitan Housing Authority, 464 F.2d 486 (6th Cir. 1972), affirming the denial of a preliminary injunction that would have required demolition of a nearly completed minority-area project. Such a remedy, the court points out, would be undesirable in light of the serious housing shortage in Cincinnati. See also Gautreaux v. Romney, 457 F.2d 124, 127 (7th Cir. 1972), reversing Judge Austin in his enjoining of Model Cities funds in an attempt to pressure the City Council to provide new public housing. The Court of Appeals held that the adverse effect on the interests of thousands of Model Cities Program beneficiaries outweighed the potential benefit of such a supplementary remedy.

86304 F. Supp. 736 (N.D. IIl. 1969).

87 The Chicago Housing Authority has finally announced, nearly five years after the Gautreaux judgment order, that it will build the new units in White areas of the city. Chicago Sun Times, May 10, 1974, at 54, col. 2. The district court had previously attempted unsuccessfully to require such construction by setting a timetable for the proposal of acceptable sites, Unpublished Order (N.D. Ill. July 20, 1970), aff'd, 436 F.2d 306 (7th Cir. 1970), cert. denied, 402 U.S. 922 (1971); cutting off HUD Model Cities funds, 332 F. Supp. 366 (N.D. Ill. 1971), rev'd, 457 F.2d 124 (7th Cir. 1972); and suspending the Illinois statute that required City Council approval of sites before their acquisition, 342 F. Supp. 827 (N.D. Ill. 1972), aff'd, 480 F.2d 210 (7th Cir. 1973), cert. denied, 94 S. Ct. 895, 896 (1974).

88304 F. Supp. at 738-39, 741. The situation is unlike that in Palmer v. Thompson, 403 U.S. 217 (1971), where the Supreme Court held that the closing of all public swimming pools in Jackson, Mississippi, cured the prior denial of equal protection caused by their segregated operation. In Palmer, the violation was terminated by a complete elimination of the public facility and no subsequent indirect support of segregated private facilities. See Griffn v. County School Bd., 377 U.S. 218 (1964). Where a local housing authority continues to operate existing public housing on unconstitutionally chosen sites 
When the segregation results solely from discriminatory tenant assignment, the most effective remedy would be to require immediate reassignment of all public housing units within the locality according to nonracial criteria. If the number of projects is substantial and the turnover rate fairly high, however, it may be sufficient to permit the assignment of units without regard to race as they are vacated in the natural course. ${ }^{89}$ The most acceptable nonracial criterion is likely to be a freedom-of-choice plan. ${ }^{\circ 0}$

In some instances, however, prior racial discrimination will have so aggravated the climate of segregation that a freedom-of-choice plan will not be sufficient to eliminate strong restrictive influences and to allow the free exercise by applicants of the choice of living in integrated housing.91 In such cases, affirmative obligations to counteract those restrictive influences will remain. ${ }^{92}$ Those obligations can be satisfied by the introduction of programs that will provide sufficient encouragement towards integration to counteract the segregative effects, ${ }^{93}$ or by forced integration until the prior attitudes are eliminated. ${ }^{94}$

\section{Meeting the Remedial Standard Under Future Housing Programs}

There are strong indications that current federal housing programs will be modified considerably within the next several years. ${ }^{95}$ It seems

or to grant subsidies within a segregated system of their own creation, they continue to violate the constitutional guarantee of freedom from discrimination.

89 See Taylor v. City of Millington, 476 F.2d 599 (6th Cir. 1973). See generally note 85 supra.

90 See note 65 supra.

91 Although the constitutional violation is in the system of discrimination, not in the segregation it produces, the results of a freedom-of-choice program should be examined for the information they impart about subtle barriers to nonracial access that remain. While no longer explicitly coercive, such barriers are a direct result of prior state discrimination. Even allowing for group cohesion, it may still fairly be assumed that some proportion of Blacks either prefer or do not object to living in integrated housing and neighborhoods. See Ackerman, Integration for Subsidized Housing and the Question of Racial Occupancy Controls, 26 STAN. L. Rev. 245, 266-69 (1974). Thus where a newly-applied freedom-of-choice or two-refusal (see note 65 supra) tenant assignment system produces no change in racial occupancy patterns, the constitutional violation should be held not to have been cured, and an objective or no-refusal system should be applied. The situation will be more difficult, however, if there is no possibility of such objective assignment, as under a housing allowance system that allows some of the program beneficiaries to seek housing in the private market. See text and notes at notes 98-107 infra. 92 Cf. Green v. County School Bd., 391 U.S. 430 (1968).

93 See, e.g., Gautreaux v. Chicago Housing Authority, 304 F. Supp. 736, 739-41 (N.D. Ill. 1969). The judgment order sets limits on new project size, project concentration, and project occupancy by site area residents, and requires the compilation of a new waiting list after intensive publicity as to the availability of White-site public housing.

94 See Swann v. Charlotte-Mecklenburg Bd. of Educ., 402 U.S. 1, 22-25 (1971).

95 President Nixon's January, 1973, moratorium on new spending in most of HUD's 
likely that Congress ultimately will replace programs providing for new public housing construction with a system of direct cash subsidies to qualifying tenants, which may be used as rent payments on the private market. ${ }^{96}$

To the extent that a constitutional violation is caused exclusively by discriminatory tenant assignment and can be remedied by an effective freedom-of-choice plan or nonracial selection procedure, the shift to a cash subsidy program will have little effect on the ability of courts to fashion an appropriate remedial order. Cash subsidies, however, will not be sufficient to cure the constitutional violation caused by discriminatory tenant assignment if the past practices of the state have aggravated the climate of segregation so as to reduce the inclination of Blacks or Whites to choose integrated housing and limit the availability of such housing for those who desire it. Similarly, racially discriminatory site selection may effectively increase the stock of accessible low-income housing in Black areas without a concomitant increase in White areas, ${ }^{97}$ and, except to the extent that private White-area landlords make low-income units available on a nondiscriminatory basis, Blacks will be unable to find integrated housing. In both of these situations the Black housing applicant is denied his right to nonsegregated housing because of state-imposed racial discrimination.

An appropriate remedy would, therefore, require the state to take

programs was followed by declarations of his intention to shape future housing programs around direct cash assistance to low-income tenants and use of existing housing stock. Congress has acted in the direction of Administration proposals. See note 9 supra.

98 The bill passed in the Senate on March 11, 1974, differs from the Administration's bill in that it sets a limit on spending under the expanded Experimental Housing Allowance Program, refrains from declaring a policy of favoring direct cash assistance as the general solution to housing needs, refrains from setting a specific restriction on the power to build new low-income housing without a determination that the private supply is inadequate, and provides no termination date for HUD's authority to enter new contracts for low-income housing assistance. Compare S. 3066, 93d Cong., 2d Sess. at ch. II, \& 201, and ch. VIII, \& 802 (1974) (the bill ultimately passed by the Senate), with S. 2507, 93d Cong., 1st Sess. at Title I, §§ 102, 104, and Title III, § 301 (1973) (the Administration bill).

The Senate's version, however, increases the authorization for the Experimental Housing Allowance Program, and enumerates a comprehensive list of specific issues it is to address. See 12 U.S.C. \& 1701z-3 (1970). The housing allowance variables currently under study are 1) payment formula, 2) conditions imposed on use of the allowance, 3) nonmonetary supplementary assistance to recipients, 4) administrative mechanism, and 5) coverage and scale of the program. 1 HUD, Ann. Rep. of Experimental Housing Allowance Program I (1973).

See generally HUD, Housing IN THE SEVENTIES (1973) (the report of the housing study); Peabody, Housing Allowances, THE NEw RePUblic, March 9, 1974, at 20.

97 Under the housing allowance program, the court will be able to order new construction neither by the local authority, because of a lack of fiscal capability, nor by HUD, because of its sovereign immunity defense, see note 84 supra. 
action to increase the existing amount of integrated low-income housing. Such action not only would enlarge the supply of housing available to Blacks who would prefer not to live in segregated dwellings, but also would effectively serve to moderate the climate of segregation imposed by the state. Since under the cash assistance program HUD cannot be forced to finance new housing; ${ }^{98}$ the increase in the stock of integrated housing units must be created by the removal of racial restrictions from private housing and by active encouragement of integration, at least until all indirect barriers are eliminated. The actions necessary to this remedy will almost certainly affect adversely the rights of persons who were not parties to the lawsuit. Courts have recognized, however, that an adverse effect on persons who may have no connection with the constitutional violation is at times an unavoidable hardship of ending racial discrimination. ${ }^{99}$ Unnecessarily broad interference with the rights of third parties will, however, be reversed as an abuse of the court's discretion.100 It is within this framework that courts must fashion remedies that utilize the direct cash assistance program.

The courts have available to them four general remedial schemes that will increase the existence of integrated housing in the private market. These schemes will be discussed in order of their effectiveness. As the remedies become more effective, however, they also create a greater adverse impact on the rights of third parties.

1. Nonmonetary Affirmative Assistance. The first remedy involves nonmonetary affirmative assistance for Black recipients. This assistance may include education and information services about the housing market, the accompanying of recipients on their trips to inquire about housing openings, aid in the following up of initial inquiries, and stricter and more vigorous enforcement of federal and local fair housing laws. ${ }^{101}$

98 The re-creation of a construction-financing program would constitute "affirmative action" such as cannot be ordered if the sovereign immunity defense is raised. See Larson v. Domestic \& Foreign Commerce Corp., 337 U.S. 682 (1949); note 84 supra. If all housing programs were terminated, sovereign immunity might bar all types of relief from the federal and state governments. It is extremely unlikely, however, that all housing programs will be discontinued.

99 Swann v. Charlotte-Mecklenburg Bd. of Educ., 402 U.S. 1, 16 (1971); Norwalk CORE v. Norwalk Redevelopment Agency, 395 F.2d 920, 931-32 (2d Cir. 1968).

100 See Gautreaux v. Romney, 457 F.2d 124, 128-29 (7th Cir. 1972), holding that an injunction against release of HUD funds in a nonhousing-related program was an abuse of discretion, on the ground that parties adversely affected by the fund cut-off were innocent third parties, or even members of the plaintiff class itself.

101 Different types of nonmonetary assistance are being tried as part of the Experimental 
Although such affirmative assistance may involve differential treatment that disadvantages housing allowance recipients to whom it is not available, the burden on innocent parties is relatively light. The assistance is tailored to the specific end of helping Black recipients who desire to live in White areas overcome discriminatory barriers. The unavailability of such assistance to White recipients or to Black recipients who choose to live in Black areas is not a significant disadvantage since it would be superfluous to their full and effective use of their housing allowances. The usefulness of this remedial scheme is, however, limited. Where there are long-standing patterns of segregation, the program is not likely to encourage many Blacks to seek housing in White areas, and it will do nothing to induce Whites to integrate predominantly Black housing. This remedy would seem, therefore, to be effective only where there is both ample housing in White areas to accommodate a substantial number of Black residents and minimal community opposition to integration.

2. Bonus Payments. In most instances a more effective remedy will be required. One such remedy involves a system of favored treatment in the payment formula. For example, a bonus might be granted Black recipients who spend their subsidy outside an area of minority concentration. This bonus would tend to overcome the Black recipient's hesitation to settle in areas from which he has always been excluded in the segregated public housing system. A concomitant effect may be the settling of Whites in Black areas. If the housing allowance to Blacks seeking to settle in White areas is higher than that for Whites seeking to settle in the same areas, then Blacks could outbid Whites for the available housing, forcing Whites to accept housing elsewhere, some presumably in Black neighborhoods. A similar bonus could, of course, be offered to Whites who settle in Black areas. Such a bonus, however, would lack the compensatory justification that has been articulated as a reason for giving bonuses to Blacks, ${ }^{102}$ but if the size of the bonus is sufficient to overcome the substantial hesitancy of Whites to move

Housing Allowance Program. HUD, Ann. ReP. OF Experimental Housing Allowance Program, supra note 96 , at 10 . No results, however, have as yet been reported.

Cf. Garrett v. City of Hamtramck, 357 F. Supp. 933 (E.D. Mich. 1973) (judgment order), where the court required relocation assistance to Black displacees of a moderateincome urban renewal area. The assistance included acquisition for rental to displacees of the homes of some of the persons who applied to move into the new project, the rewriting and strict enforcement of the local fair housing law, provision of personal escorts for displacees in their inquiries in the open housing market, attempts to persuade private owners thus contacted to sell or rent on a nondiscriminatory basis, and the payment of some moving expenses. Id. at 928, 932-33.

102 See text at notes $98-99$ supra. 
into ghetto areas, the plan would result in increasing the stock of integrated housing in formerly all-Black as well as formerly all-White areas.

The adverse impact of this remedy on the rights of third parties is substantial. The bonus for Blacks settling in White areas constitutes favored treatment of certain Blacks over Whites and over those Blacks who choose to maintain residence in minority areas. The disfavored class, however, consists mainly of those who were not injured by the original violative government restriction, ${ }^{103}$ and no party is totally denied the benefit of the housing allowance program.

3. Access Quotas. A stronger measure, involving a variation of the conditions imposed on the use of the allowance, is an "access quota,"104 which would require that a certain number of Black recipients must have obtained residence in nonminority areas before any more allowances may be given to Whites for use in that area. Under this remedy, the defendant agency has the burden of identifying and encouraging minority recipients who are willing to settle in nonminority areas. The remedy also increases the differential between what Black recipients and White recipients can bid for housing in White areas. The access quota in its harshest form temporarily prevents Whites from obtaining housing in certain areas, but this may not outweigh the necessity for such a remedy when long-standing discrimination in site selection and tenant assignment has resulted in a great hesitancy on the part of Blacks to seek integrated housing and a tight supply of lowincome housing in white areas.

4. Integration or Dispersion Quotas. An "integration quota"105 places a ceiling on the number of Blacks who can use their allowance to settle in Black areas. ${ }^{106}$ This type of quota would require a substantial number of Blacks to settle in White or integrated areas if they are to be able to use their housing allowances. Coupling an integration quota

103 This is unlike the fund cut-off remedy in Gautreaux. See note 100 supra.

104 See Ackerman, supra note 91, at 247.

$105 I d$. The logic of the integration quota, to prevent resegregation in initially White areas, is based upon the notion of a tipping point, and minority concentration beyond that point makes the area Black for purposes of the operation of the quota. In the initially Black area, the integration quota operates to disperse minority recipients.

106 An alternative formulation of this integration quota is the tentative suggestion made by one HUD official that a condition of minority concentration in any neighborhood would place housing in that neighborhood below a level of "standard housing" that might be required for use of the allowance. This seems essentially a resurrection of the FHA's "red-line" procedure. Interview with Nancy Chisholm, Policymaker, Division of Policy Development, Office of Equal Opportunity, HUD, in Washington, D.C., November 12,1973 . Whatever the propriety of such a system when voluntarily undertaken, its evaluation as a remedy is subject to the same analysis as a pure integration quota. 
with an access quota will result in an even greater quantity of integrated housing.

The interplay of access and integration quotas would permit the use of housing allowances only in truly integrated housing. There seems to be little justification, however, for forcing Blacks to integrate under threat of such a severe penalty. ${ }^{107}$ The constitutional violation consisted of a denial of true freedom of choice, not the absence of integrated housing. In addition, the inequities of impairing the rights of Whites through the imposition of access quotas are compounded by restricting the freedom of Blacks to choose where they would like to live. It seems anomalous to affect adversely the rights of those same parties who have been most injured by the past discrimination and who are the intended beneficiaries of the remedy.

\section{CoNCLUSION}

Open discrimination in site selection and tenant assignment has largely been abandoned, and the covert practices that remain are substantially more difficult to prove. Although proof of covert discrimination must be indirect, with a necessarily tenuous link of culpability in a moral sense, a finding of such discrimination is appropriate where statistical evidence plus evidence as to the current and historical operation of explicit policies strongly indicates the systematic use of the criterion of race.

Courts that have found such discrimination have been working to construct appropriate remedies under the current housing programs, but the problem of remedies will be made more complex by the replacement of federal construction-financing programs with federal cash allowance programs. It will be possible, however, for a court to structure the cash assistance program so that the use of bonuses, access quotas, and integration quotas effectively eliminates state-maintained denials of the rights of minorities to obtain housing without restriction on account of their race.

\section{John I. Stewart, Jr.}

107 See text at notes 77-81 supra. There has been some suggestion that the exclusory effects of such a quota voluntarily undertaken in furtherance of a statutory policy of promoting integration can be justified in the interest of preventing resegregation. See Otero v. New York City Housing Authority, 484 F.2d 1122 (2d Cir. 1973); cf. Ackerman, supra note 91. 